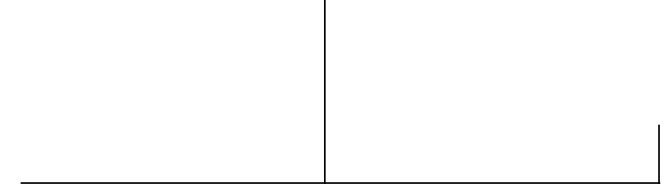

Rev. Latinoam. Psicopat. Fund., VI, 1, 175-177

\author{
Estresse \\ Maria Auxiliadora de Almeida Cunha Arantes e \\ Maria José Femenias Vieira \\ São Paulo: Casa do Psicólogo, 2002
}

\title{
A sombra, o bom e o mau estresse
}

\section{Marilucia Melo Meireles}

Afinal, o que é estresse?

A resposta a esta pergunta encontra-se no livro Estresse escrito a quatro mãos pela psicanalista Maria Auxiliadora de Almeida Cunha Arantes, responsável pelos quatro capítulos que compõem sua primeira parte, e pela médica Maria José Femenias Vieira, autora do quinto capítulo.

Editado pela Casa do Psicólogo, em abril de 2002, integra a Coleção Clínica Psicanalítica, dirigida por Flávio C. Ferraz, que se propõe tratar, no terreno psicanalítico, de temas atuais do campo das psicopatologias.

Apesar de ser, hoje, um termo quase banalizado, presente até nas camisetas, com a inscrição No stress, que são vendidas em nossas praias, o conceito de estresse tornou-se fundamental para a compreensão das relações entre o indivíduo (humano ou animal) e seu entorno, sendo hoje impossível dispensá-lo, seja na compreensão do homem contemporâneo seja no estudo da ecologia.

Maria Auxiliadora inaugura, em sua descrição de estresse, o uso do termo figura, expressão mais específica da terminologia psicanalítica, à medida que o conceito de síndrome é mais pertinente ao campo clínico da medicina. Ressalto este ponto porque denota o cuidado da autora em circunscrever a sua escrita.

A surpresa contida nesta publicação, no entanto, vai além. Juntamse duas pesquisadoras em seus respectivos campos de trabalho e se 
debruçam sobre este assunto para garimpar o que há de precioso na literatura e acrescentar suas contribuições.

Maria Auxiliadora Arantes nos encaminha historicamente para o ano de 1936 e nos conta como o jovem médico e pesquisador austríaco Hans Selye, conhecido como o pai do estresse, observou e conceituou a presença de uma reação orgânica, inespecífica, que agride, de maneira repetitiva e desenfreada nosso organismo e também o dos animais, que vem e que vai, que aparece e desaparece, produzindo respostas emocionais e/ou fisiológicas causadas pelos agentes estressores, seu grande vilão.

É bom esclarecer que, em sua origem, estresse é um conceito que provém da física e que se estendeu para as ciências do comportamento e para a biologia. Esta reação - também chamada em seus primórdios de Síndrome Geral de Adaptação - seria, em última instância, um sinal de alarme, prevenindo-nos quanto ao surgimento de uma ruptura da homeostase orgânica e da possível eclosão de uma doença. Teríamos então, a partir desse sinal, primeiramente, a fase de alarme, seguida por um período de resistência e busca de equilíbrio e, finalmente, a fase de exaustão-colapso propriamente dita.

Poderíamos seguir de maneira linear e apresentar ao leitor uma resenha de todo o percurso feito pelas autoras neste livro. Vou adotar, porém, um caminho "sem estresse", indo diretamente ao ponto.

É possível viver sem estes agentes estressores numa civilização como a nossa?

Para Maria Auxiliadora, parece impossível. Agrega que o estresse também é necessário para a manutenção da vida. Daí a presença do bom e do mau estresse. É um sofrimento do qual ninguém escapa, fundamental para a nossa sobrevivência. Algumas vezes é amplificado, em outras, não. Medo, temor, desespero, desamparo, pavor, terror, são expressões do sofrer humano que buscam evidenciar a presença destes agentes estressores. Inútil fugir, pois a dor não passa, já nos dizia a canção. Mas o que fazer, então?

A autora, auxiliada pela belíssima metáfora da sombra, nos diz que: "Da sombra não se pode escapar” e acrescenta mais: “... esta é uma crença antiga que impedia os homens primitivos de saírem ao sol do meio-dia, pois deixariam de ver sua sombra: ela é que lhes garantia o 'algo' que havia dentro deles e que deveriam preservar” (p. 57). Casando o estresse com a angústia, busca a saída possível que permite aos indivíduos a convivência com este estado estressante de resistência ao existir humano.

Para ela, a angústia, "com toda sua majestade e a realeza do mundo das sombras, se impõe como uma condição e não como uma escolha" (p. 57) e lança a hipótese de ela ser uma "vacina sinal" inerente ao momento "em que o corpo convoca suas defesas para não sucumbir ao ataque sofrido" - segundo momento, o da resistência à presença do estresse. 


\section{RESEN HA \\ DE LIVROS \\ ano VI, n. 1, mar/2003}

Na verdade, é o sinal da angústia que nos vacina, prevenindo-nos quanto ao estresse, preparando-nos para nos defendermos dele por meio da elaboração ou da descarga. A angústia nos capacita a viver.

Daí a conclusão: "Sendo do registro do psíquico, poderia ser elaborada, e não necessariamente ficar refém de uma repetição que oprime. Sendo somática, poderia deixar escoar no corpo sua dor e não necessariamente entrar em um colapso irreversível. Sendo originária, traz a marca do humano do qual não se pode escapar” ( $p$ 58). Para ela a angústia, lugar de resistência, termina por ser esta grande estrada "por onde transitam os afetos mais somáticos e as dores mais psíquicas”.

Uma conceituação, para mim nova, presente neste livro é a de síndrome de burnout surgida em 1973 e conceituada por Freudenberg. Trata-se de uma outra modalidade de manifestação de estresse, mais radical, semelhante ao colapso dos motores dos jatos e foguetes (p. 87), um estado extremo de esgotamento encontrado principalmente nas relações de trabalho. Maria Auxiliadora dedica, neste livro, um espaço importante para mostrar o lugar que o trabalho ocupa em nossas vidas, talvez exigindo-nos uma outra resenha para discorrermos sobre este tema. Ressalto, porém, que sua preocupação ao introduzir este termo, burnout aponta para a necessidade cada vez mais premente de atentarmos para a diversidade de mecanismos individuais, psíquicos e somáticos presentes nas respostas aos agentes estressores.

Maria José Femenias, no quinto capítulo, retoma a definição de estresse intrínseco ao campo da medicina, oferecendo-nos, a nós, leigos, a possibilidade de entender de maneira rigorosa e simples - e isso é ótimo -, as ações e respostas orgânicas dos sistemas nervoso, endócrino e imunológico, seja em seu funcionamento regular seja quando se manifestam as patologias.

Esta autora também destaca os efeitos positivos do estresse quando este resulta da luta para manter a homeostase do organismo em que predominam manejos adequados e criativos diante das mudanças inerentes ao desenvolvimento humano e dos "eventos estressores" (p 120).

Como disse acima, este livro corresponde à pretensão das autoras de discorrer sobre um tema amplo, esclarecendo áreas onde a indiscriminação se insinua, à medida que, como um verdadeiro curinga, serve para diagnosticar qualquer sintoma incomunicável.

Sobretudo, este livro busca ser um ato convocatório à sociedade empresariado, trabalhadores e governo -, às ciências do comportamento alinhadas às do campo médico, para que todos desenvolvam ações compartilhadas, uma vez que o estresse resulta de uma concepção de sofrimento humano pessoal, coletivo, ecológico e organizacional.

Ao leitor fica a indicação deste livro. 